\title{
Cardiac energy metabolism and oxygenation during exercise in the hypertensive heart
}

\author{
Sairia Dass ${ }^{1,2^{*}}$, Rina Ariga ${ }^{1}$, Emily Sever ${ }^{1}$, Lowri E Cochlin ${ }^{1}$, Joseph Suttie ${ }^{1}$, Cameron Holloway ${ }^{1}$, Masliza Mahmod ${ }^{1}$, \\ Theodoros D Karamitsos ${ }^{1}$, Stefan Neubauer ${ }^{1}$ \\ From 17th Annual SCMR Scientific Sessions \\ New Orleans, LA, USA. 16-19 January 2014
}

\section{Background}

Hypertension (HPT) is an important risk factor for heart disease worldwide. It is already established that in hypertension there is an abnormal oxygenation response to stress (by exploiting the paramagnetic properties of deoxyhemoglobin, blood oxygen level-dependent, BOLD). Additionally, abnormal resting cardiac energetics (phosphocreatine/adenosine triphosphate, $\mathrm{PCr} / \mathrm{ATP}$, as measured by 31Phosphorus MR Spectroscopy, 31P MRS) has been reported. However, it is not known if this energetic profile worsens with the increasing energy demand of exercise, and if so, if the blunted Oxygen supply response may contribute to this. Understanding this relation can lend new insights into the pathophysiology and management of hypertensive heart disease. We hypothesized that cardiac energetic are abnormal at rest and are further impaired during acute exercise in HPT, and that this impairment is related to abnormal oxygenation during stress.

\section{Methods}

Cardiac 31P MRS (3T) was performed in 17 hypertensive patients, and 20 age and gender matched normal controls at rest and during 8 minutes of leg exercise lying prone, with $2.5 \mathrm{~kg}$ weights attached to both legs. BOLD (using a T2-prepared sequence) and first-pass perfusion images (using a saturation recovery fast-gradient echo sequence and $0.03 \mathrm{mmol} / \mathrm{kg} \mathrm{Gd}$-DTPA bolus) were also acquired at stress (4-6 minutes i.v. adenosine, $140 \mu \mathrm{g} / \mathrm{kg} / \mathrm{min}$ ) and rest. Signal intensity change (SI $\Delta$ ) and myocardial perfusion reserve index (MPRI) were measured from BOLD and perfusion images, respectively.

\section{Results}

Increases in rate pressure product with exercise (HPT $74 \pm$ $44 \%$, normal $73 \pm 40 \%, \mathrm{P}=0.71$ ) and adenosine stress (HPT $73 \pm 46 \%$, normal $73 \pm 37 \%, \mathrm{P}=0.67$ ) were similar. In normals, there was no change in PCr/ATP during exercise (rest: $2.16 \pm 0.08$, exercise: $2.15 \pm 0.06, \mathrm{P}=0.97$ ). Resting PCr/ATP was significantly reduced in HPT (1.63 \pm $0.07, \mathrm{P}=0.001$ vs controls), and during exercise, there was a further reduction in $\mathrm{PCr} / \mathrm{ATP}(1.49 \pm 0.07, \mathrm{P}=0.03$ vs rest). There was a significantly reduced BOLD SI $\Delta$ response in HPT (BOLD SI $\Delta: 10 \pm 2 \%$; normal $20 \pm 0.01 \%$ $\mathrm{P}=0.004)$. MPRI was also significantly reduced in HPT $(1.6 \pm 0.07$; normal $1.9 \pm 0.02, \mathrm{P}=0.001)$. There was a weak but significant correlation between BOLD SI $\Delta$ and MPRI per segment, $(\mathrm{R}=0.25, \mathrm{P}=0.006)$. Importantly, in $\mathrm{HPT}$, there was a significant correlation between exercise $\mathrm{PCr} / \mathrm{ATP}$ and BOLD SI $\Delta(\mathrm{R}=0.51, \mathrm{P}=0.04)$, Figure 1 .

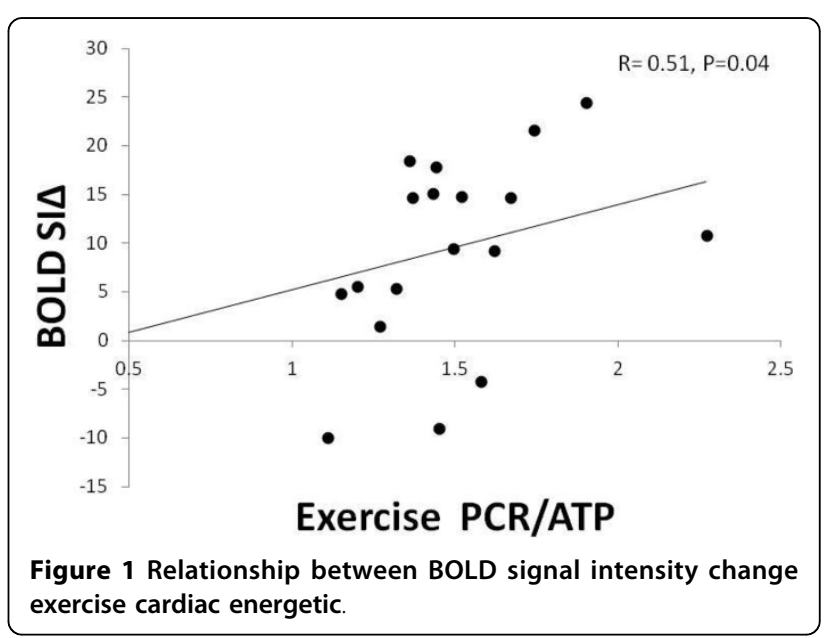

OCMR, University of Oxford, Oxford, UK

Full list of author information is available at the end of the article 


\section{Conclusions}

During exercise, the pre-existing energetic deficit in HPT is further exacerbated and correlates with the blunted myocardial oxygenation response to vasodilator stress. In the hypertensive heart, myocardial tissue hypoxia during stress may play a significant pathophysiological role by inducing adverse metabolic changes in the myocardium.

\section{Funding}

British Heart Foundation.

\section{Authors' details}

'OCMR, University of Oxford, Oxford, UK. ${ }^{2}$ Internal Medicine, St Joseph Mercy Hospital, Ann Arbor, Michigan, USA.

Published: 16 January 2014

doi:10.1186/1532-429X-16-S1-0109

Cite this article as: Dass et al:: Cardiac energy metabolism and oxygenation during exercise in the hypertensive heart. Journal of Cardiovascular Magnetic Resonance 2014 16(Suppl 1):0109.

Submit your next manuscript to BioMed Central and take full advantage of:

- Convenient online submission

- Thorough peer review

- No space constraints or color figure charges

- Immediate publication on acceptance

- Inclusion in PubMed, CAS, Scopus and Google Scholar

- Research which is freely available for redistribution

Submit your manuscript at www.biomedcentral.com/submit
C Biomed Central 